\title{
Characteristic aspects of alveolar proteinosis diagnosis
}

\author{
Aspectos característicos do diagnóstico da proteinose alveolar
}

Thiago Prudente Bártholo'; José Gustavo Pugliese²; Luiz Carlos Aguiar Vaz ; Cláudia Henrique da Costa4; Rogério Rufino

\section{key words}

Pulmonary proteinosis

Crazy paving

GM-CSF

\section{abstract}

Alveolar proteinosis is an uncommon pulmonary disease characterized by an accumulation of surfactant in terminal airway and alveoli, thereby impairing gas exchange and engendering respiratory insufficiency in some cases. Three clinically and etiologically distinct forms of pulmonary alveolar proteinosis are recognized: congenital, secondary and idiopathic, the latter corresponding to $90 \%$ of the cases. In this case report we present a young male patient that was diagnosed with alveolar proteinosis. Computed tomography of the thorax, bronchoscopy and transbronchial biopsy were performed. The histopathologic aspect was characteristic. The patient was discharged in good health conditions and remains asymptomatic to date.

\section{resumo}

Proteinose alveolar é uma doença pulmonar incomum caracterizada pelo acúmulo de surfactante nas vias aéreas terminais e nos alvéolos, alterando a troca gasosa e, em alguns casos, promovendo insuficiência respiratória. Três formas clínicas e etiologicamente distintas de proteinose alveolar são reconhecidas: congênitas, secundárias e idiopáticas (mais de $90 \%$ dos casos são de etiologia idiopática). Neste relato, apresentamos um homem jovem que foi diagnosticado com proteinose pulmonar. Tomografia computadorizada de tórax, broncoscopia e biópsia transbrônquica foram realizadas. O aspecto histopatológico foi característico. 0 paciente teve alta, com boas condições de saúde, e encontra-se assintomático nos dias de hoje. unitermos

Proteinose alveolar

Pavimentação em mosaico

GM-CSF

1. Médico do Hospital Universitário Pedro Ernesto (HUPE); pneumologista da Universidade do Estado do Rio de Janeiro (UER)).

2. Médico do HUPE; pneumologista da UER].

3. Doutor em Anatomopatologia; professor adjunto da disciplina de Anatomopatologia da UERJ.

4. Professora adjunta da disciplina de Pneumologia e Tisiologia da UER); coordenadora da disciplina de Pneumologia e Tisiologia.

5. Pós-doutorado pelo National Heart and Lung Institute (Londres); chefe da Unidade Projetos do HUPE/UER). 


\section{Introduction}

Pulmonary alveolar proteinosis (PAP) is a rare disorder that accumulates lipoproteins in alveolar space. Idiopathic PAP is the most common form and is regarded as an autoimmune disease caused by auto antibodies to the granulocyte-macrophage colony stimulating factor (GM-CSF). High-resolution computed tomography shows patchy, ground glass opacifications (GGOs) with superimposed interlobular septal and intralobular thickening, a pattern commonly referred to as "crazy paving" ${ }^{\prime \prime}(7)$. The clinical course of the disease is variable, ranging from respiratory failure to spontaneous resolution. We present in this case report a young man that had fever and dry cough that initiated one month before the admission in our hospital. After investigation a diagnosis of pulmonary proteinosis was made.

\section{Clinical report}

A 30 year-old man presented with fever and dry cough. The high fever started one month earlier and after a week a dry cough appeared with a mild headache. He looked for an otorrhinolarigologist, but his symptoms carried on. He was admitted in another hospital where he used for two weeks ceftriaxone + oxacilin + amicacin. The fever and the dry cough did not remit. The blood exams were unremarkable and a chest computadorized tomography (CT) showed bilateral patchy diffuse GGO that was characteristic of a crazy paving pattern. The patient was transferred for our hospital. He was admitted for treat clinical investigation. He denied sputum production, dyspnea, hemoptysis, weight loss and anorexia. His social history was negative for smoking or alcohol. He had a medical history for asthma and allergic rhinosinusitis.

On physical examination the patient was afebrile and a little bit anxious. Respiratory rate of 20 breaths/min, heart rate of 88 beats $/ \mathrm{min}$, and blood pressure of $130 / 70 \mathrm{mmHg}$. Head, ear, nose, and throat examination was unremarkable. There was no palpable lymphadenopathy. Cardiovascular system examination was normal. Pulmonary examination revealed normal breath sounds without any rhonchi, rales, egophony, or dullness to percussion. The rest of physical examination was unremarkable. Laboratory results show complet blood count (CBC), basic metabolic panel, and liver function test results were normal. Lactate desidrogenase was 290 U/L. An HIV test result was negative.
The patient was admitted in our hospital to investigate fever and dry cough that initiates one month earlier. The physical examination was unremarkable. CT chest revealing a diffuse GGO pattern and bronchoscope was procedure (Figure 1). The bronchoalveolar lavage showed an eosinophilic material with a lot of bronchial cilindric cells with reactive alterations and the presence of alveolar macrophages. Transbronchial biopsy showed tipic respiratory epithelium, deposit of a pink intraalveolar material with mild fibrosis in the septum (Figure 2). He remains asymptomatic.

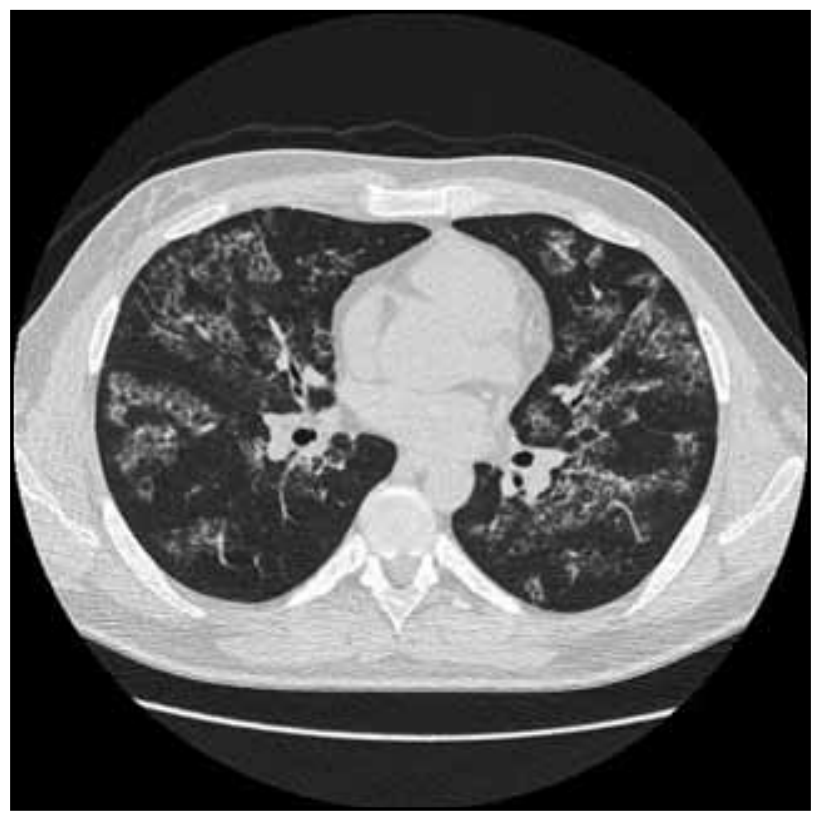

Figure 1 - Computed tomography of chest

The computadorized tomography scan shows bilateral patchy ground glass opacification.

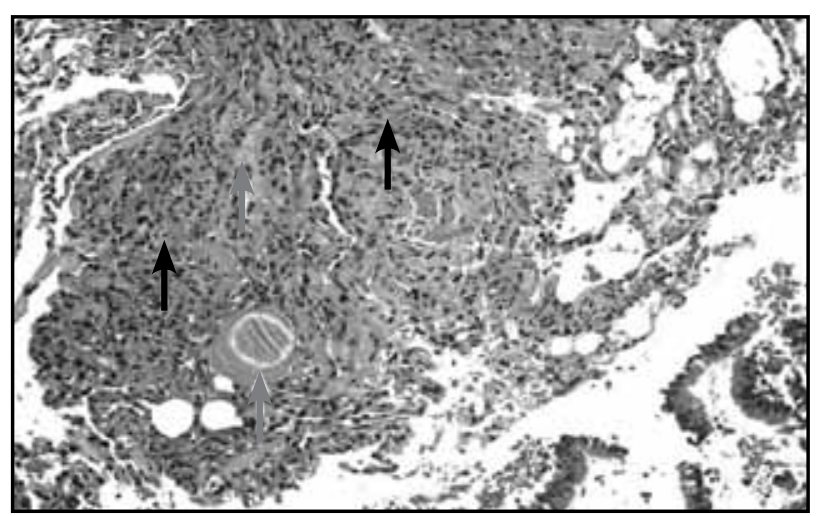

Figure 2 - Specimen from transbronchial biopsy

$H E$ (40x): the normal pulmonary parenchima contrast with the affected area that shows septal fibrosis (black arrows) and intra alveolar proteinaceous material (white arrows).

PAP is a rare clinical syndrome that was first described in 1958. Its incidence is 0.37 and the prevalence is 3.7 per million population ${ }^{(7)}$. The median age at the time of diagnosis is 39 years; most patients are men, and 72 percent 
have a history of smoking ${ }^{(9)}$. The affected individuals have a progressive accumulation of surfactant lipoproteins in the alveolar space. The alveolar space contents proteinaceous material that might be determined periodic acid Schiff (PAS). The actual lung tissue is practically normal, although a minor component of interstitial involvement is probably present in most cases ${ }^{(5)}$. PAP occurs in three clinically distinct forms: congenital, secondary and acquired (idiopathic). The congenital form comprises a heterogeneous group of disorders caused by mutations in the genes encoding surfactant protein $\mathrm{B}$ or $\mathrm{C}$ or the beta $\mathrm{C}$ chain of the receptor for GM-CSF. Secondary PAP develops in association with conditions involving functional impairment or reduced numbers of alveolar macrophages. Such conditions include some hematologic cancers, pharmacologic immunosuppression, inhalation of inorganic dust or toxic fumes, and certain infections ${ }^{(9)}$. Idiopathic PAP, the most common form, is regarded as an autoimmune disease caused by auto antibodies to the GM-CSF. The loss of GM-CSF activity caused by anti-GM-CSF antibodies may impair the normal function of pulmonary alveolar macrophages and therefore decrease the surfactant clearance ${ }^{(4)}$.

Primary PAP presents in previously health adults as progressive exertional dyspnea of insidious onset. About one third of individual complain of cough, and less commonly, fever, chest pain or hemoptysis, especially if secondary infection is present ${ }^{(3)}$. The clinical course of the disease is variable, ranging from respiratory failure to spontaneous resolution. An important feature of the disease is susceptibility to pulmonary infections, sometimes with opportunistic organisms notably Mycobacterium sp., Aspergilus spp. and Nocardia sp. ${ }^{(7,9)}$.

In acquired PAP, routine blood counts and the results of routine blood chemical analysis and urinalysis are usually normal. The serum level of lactate dehydrogenase is frequently slightly elevated and may be a useful marker of the severity of the disease. Elevations in the serum levels of carcinoembryonic antigen are of unclear prognostic value ${ }^{(9)}$. Results for ongoing clinical research studies indicate that the sensitivity and specificity of anti-GM-CSF autoantibody for primary PAP approaches 100 percent $^{(3)}$. Chest radiograph usually reveals bilateral airspace disease with an ill-fined nodular or confluent pattern, often with a perihilar predominance suggestive of the "bat wing" appearance of pulmonary edema but without other radiographic signs of left-sided heart failure. Notably, the extent of radiographic abnormalities is often disproportionately increased relative to the severity of the symptoms and physical findings. Highresolution computed tomography shows patchy, GGOs with superimposed interlobular septal and intralobular thickening, a pattern commonly referred to as "crazy paving"(9). Crazy-paving pattern can also be seen in Pneumocystis jiroveci pneumonia, acute radiation pneumonitis, pulmonary hemorrhage, usual interstitial pneumonia or drug-induced pneumonitis ${ }^{(6)}$. The results of tests of pulmonary function can be normal, but typically they show a restrictive ventilatory pattern ${ }^{(9)}$. Most cases in the past required open-lung biopsy for diagnosis, and this remains the "gold standard". Open-lung biopsy is less commonly required now, as a diagnosis of PAP can be established in approximately $75 \%$ of clinically suspected cases by the classic findings of a "milky" effluent from bronchoalveolar lavage. This fluid contains large amounts of granular acellular eosinophilic proteinaceous material with morphologically abnormal "foamy" macrophages engorged with diastase-resistant PAS-positive intracellular inclusions. In the lung biopsies specimens the characteristic features of PAP on light microscopy are the near-complete filling of the alveolar space and terminal bronchioles with PAS-positive acellular surfactant. There may be a mild interstitial lymphocytic infiltrate, however, this is not a prominent feature, and the alveolar architecture is usually well preserved ${ }^{(7)}$.

The first advance in the treatment of PAP came in November 1960 with the whole lung lavage (WLL). Most experts consider this the main treatment ${ }^{(7)}$. The purpose is to remove the lipoproteinaceous material that accumulates in the bronchi of patients with alveolar proteinosis, leading to clinical and functional improvement ${ }^{(1)}$. The WLL for idiopathic PAP is currently a safe procedure in an experienced setting, and yields durable benefit in the majority of patients ${ }^{(2)}$.

The use of subcutaneous GM-CSF therapy is a promising alternative to WLL for symptomatic patients with PAP. GM-CSF therapy improved respiratory disease in nearly one half of the twenty five patients studied by Saiprakash et al. In this study the response to GM-CSF therapy required eight to 12 weeks and was not associated with peripheral leukocytosis. All of the patients had anti-GM-CSF antibodies, which are useful in the noninvasive diagnosis of PAP. The study shows that the serum anti-GM-CSF antibody titer correlated with lung disease activity and is a predictor for responsiveness to therapy, thereby suggesting a potential option in monitoring during therapy ${ }^{(10)}$. Other form of administration could be the inhaled GM-CSF therapy. This 
form proved to be safe, effective, and provides a sustained therapeutic effect in autoimmune PAP in one serie ${ }^{(9)}$.

$P A P$ is a rare disorder that accumulates lipoproteins in the alveolar space and it has three different forms. A crazy paving pattern in thorax CT associated with a histophatological confirmation have led us to confirm this diagnosis.

\section{References}

1. AGUIAR, M. et al. Whole lung lavage: report of four cases of alveolar proteinosis. Rev Port Pneumol, v. 15, n. 1, p. 77-88, 2009.

2. BECCARIA, M. et al. Long-term durable benefit after whole lung lavage in pulmonary alveolar proteinosis. Eur Respir J, v. 23, n. 4, p. 526-31, 2004.

3. GORDON, I. O. et al. Update in nonneoplastic lung diseases. Arch Pathol Lab Med, v. 133, n. 7, p. 1096-105, 2009.

4. LIN, F. C.; CHEN, Y. C.; CHANG, S. C. Clinical importance of broncoalveolar lavage fluid and blood cytokines, surfactant protein D, and Kerbs von Lubgren 6 antigen in idiopathic pulmonary alveolar proteinosis. Mayo Clin Proc, v. 83, n. 12, p. 1344-9, 2008.

5. MORGAN, C. The benefits of whole lung lavage in pulmonary alveolar proteinosis. Eur Respir J, v. 23, n. 4, p. 503-5, 2004.
6. SEYFIKLI, Z. et al. Primary alveolar proteinosis and review of the literature. Turkish Respir J, v. 2, n. 3, p. 36-9, 2001.

7. SEYMOR, J. F.; PRESNEILL, J. J. Pulmonary alveolar proteinosis: progress in the first 44 years. Am J Respir Crit Care Med, v. 166, n. 2, p. 215-35, 2002.

8. TAZAWA, R. et al. Inhaled granulocyte/macrophage-colony stimulating factor as therapy of pulmonary alveolar proteinosis. Am J Respir Crit Care Med, v. 181, n. 12, p. 1345-54, 2010.

9. TRAPNELL, B. C.; WHITSETT, J. A.; NAKATA, K. Pulmonary alveolar proteinosis. N Engl J Med, v. 349, n. 26, p. 2527-39, 2003.

10. VENKATESHIAH, S. B. et al. An open-label trial of granulocyte macrophage colony stimulating factor therapy for moderate symptomatic pulmonary alveolar proteinosis. Chest, v. 130, n. 1, p. 227-37, 2006. 